\title{
Evaluating the Potential Impact of the East-West Rail Service on the Socio-Economic Output of Communities along Its Corridor
}

\author{
Charles Asenime \\ Department of Transport Planning and Policy, School of Transport, Lagos State University, Ojo, Nigeria \\ Email: casenime2001@yahoo.com
}

\begin{abstract}
Nigeria is a vast country with a large population and natural resources scattered almost equally along its entire land mass; these resources have been variously mined and require the use of transport to move them. They are usually moved by heavy vehicle such as rail built during the colonial era. As the economy however expands, the need to expand the rail network becomes expedient, more especially since their network is designed in a triangular form from the North East to south east and from North West to the south west of the country. This rail network has left a gapping need for rail services between the South east and South west of Nigeria more so, now that trade between the both regions has grown. This paper is therefore aimed at evaluating the potential impact of the East-West Rail service on the socio-economic output of communities along its corridor. Data used for this paper was from various fieldworks conducted along the east-west corridor between 2016-2018 to examine its economic profile and the socio economic activities of communities along the corridor. Findings from the paper show that travel time will reduce by at least $50 \%$, also, the corridor accounts for more than $30 \%$ of the total road fatalities in Nigeria, it is therefore predicted that these will reduce drastically and will promote security which has been compromised by the activities of armed bandits and herdsmen. Added to this, the volume of trade between imports from the Apapa ports complex needed in the eastern markets will increase and will have a multiplier effect on job creation and the reduction of the cost of goods. The paper concludes that the construction of this all important rail service will reduce poverty among communities along the corridor, create more jobs and improve lifestyles.
\end{abstract}

Keywords: population, resources, rail network, regions security, travel time, corridor, lifestyle

\section{Introduction}

It is easy to measure a country's prosperity by the types and level of transport infrastructure it has. A good and well linked transport infrastructure could be the difference between economic growth and poverty. When the infrastructure is in good shape, goods, services and people can easily move. Part of the UN strategy for reducing poverty by at least $50 \%$ in the Sustainable Millennium Goal 1 is the development of infrastructure that promotes economic growth and mobility. Poor transport infrastructure still remains one of the most potent challenges facing many developing economies. Many find it difficult to move, and when they do, it is often in overcrowded vehicles that are barely safe. These developments have impacted negatively on industrialisation, economic growth, regional development cooperate and individual productivity. Part of the problems of developing economies, according to Oyesiku, (2010) is primacy of growth; rural urban migration; inadequacy and over-utilization of basic services among others

The impact of a functional transport infrastructure on national economy and development has elicited debates from various planners for instance Hoyle \& Knowles (1996), discussed that, a relative lack of intermodal choice is a major characteristic of transport in developing countries. They went further to show that restrictive impact of limited transport availability is a major factor affecting development in low income countries, while on the other hand, the availability of a wide range of modes facilitated socio economic progress in countries of the west. According to Boarnet (1996), the economic benefit from inter regional transport infrastructure is simply a redistribution of activities of communities along its corridor. Transport infrastructure is therefore a pivotal element on which the socio-economic development of a nation is built (NTS, 2006). 
One of the biggest problems of development in sub Saharan Africa is the restriction placed on mobility by deficient transport infrastructure. Many people in Africa cannot move easily or access social facilities or markets due to poor transport infrastructure due to transit capacity. Hoel \& Sadek (2008) refer to transit capacity as the movement of persons and vehicles under a specified operating condition without unnecessary delays, hazards or restriction. Once a transit system is unable to meet these factors, then its capacity is low. For instance, in many sub-Saharan African Countries, majority of School Children in rural areas and urban trek at least $5 \mathrm{~km}$ daily to and from school; also, many women have died during pregnancy, because they cannot access primary health centers for basic ante natal checkups. Farm produce are wasted after harvest due to seasonality of roads, many households in urban areas cannot access jobs and other urban support facilities due to poor transport infrastructure. These conditions become even more unacceptable when many travelers are trapped in congestion between cities and between rural areas for very long hours due to poor or inadequate transport infrastructure. These conditions are prevalent in most Sub-Saharan African cities, especially in Nigeria where the road network has deteriorated and there are no connecting rail lines to many cities and rural areas.

There is currently no existing rail line linking the East and the west; the use of road transport which is very flexible, was given too much attention which has eroded the rail share over passenger and Freight transportation. (Hanson \& Guiliano 2004). Another factor according to the Asian Development Bank (2010) why the railway has not been fully developed is because of the reluctance of railway administration bodies to reform and be modernized, for instance it took a modern 50 years for the railway Act of 1953 in Nigeria to be modernized and also the inability of the Nigerian Railway (NRC) to realize the full potential of the railway over long interregional travels. That is why there was no rail link between the two regions, all movements depend more on Federal roads, which has put them in a bad state and have outlived their design capacity and age. They have become death traps. Various accident data shows that most road fatalities occur on Federal roads between states. This has ranked road traffic Crashes as the second most important cause of death in Nigeria after health-related diseases.

In a bid to improve the interaction between the eastern region and the west, the Federal government has proposed the construction of the east-west rail line and has budgeted massively for road construction and rehabilitations for over a decade in its annual budget to ensure travelers have alternatives. These rehabilitation and constructions are strategically planned to ensure mobility and resource balance between these two regions (JBN, 2016). This is why the federal government went back to the Master Plan for Integrated Transportation Infrastructure (MITI)", issued in 2002. The plan outlined various measures and infrastructure to be considered by government to ensure efficient movement of resources, information, goods and persons.

This paper is aimed at evaluating the potential socio-economic impact of the proposed east-west rail line on some selected agglomerations along its corridors. This is with a view of analyzing the economic activities of such areas and the potential impact of how good rail infrastructure will produce economic growth and the cascading effects. Its objectives are to: specifically highlight the impact of rail on natural resources of the two regions and the challenges of utilizing them; mobility of travelers; market thresholds; life style change, carbon footprint and general wellbeing of the two regions.

\section{Methodology}

Data on proposed road construction and rehabilitation was sourced from the national budgets from 20162019. The data was tabulated to show regional spread from which socio-economic potential impacts were analysed. Data from the National Atlas of Nigeria were utilized, also, reports from the Master Plan for Integrated Infrastructure (MITTI) was utilized coupled with the Nigeria Transport Survey (NTS) and Nigeria National Accounts (NNA). These were complemented with data from the Nigeria Bureau of statistics (NBS) and journal regional development and trade 


\section{Results and Discussion}

\subsection{Proposed East-West Rail}

The Calabar- Lagos East-West rail link is proposed to be the major link between eastern and western Nigerian. It will pass through Calabar, Uyo, Aba, Port Harcourt, Yenogua, Otuoke, Ughelli, Warri, Sapele, Benin, Ore Ijebu Ode and Lagos. With a target of covering all the seaports along its corridor which are Lagos Port Complex, Calabar Port, Rivers Port Complex, Delta Port and Onne Port. The trains are designed to travel at $120 \mathrm{~km} / \mathrm{hr}$, covering a distance of an estimated distance of $860 \mathrm{~km}$ length. Table 1 shows the states it will run through and their population estimates as at 2016

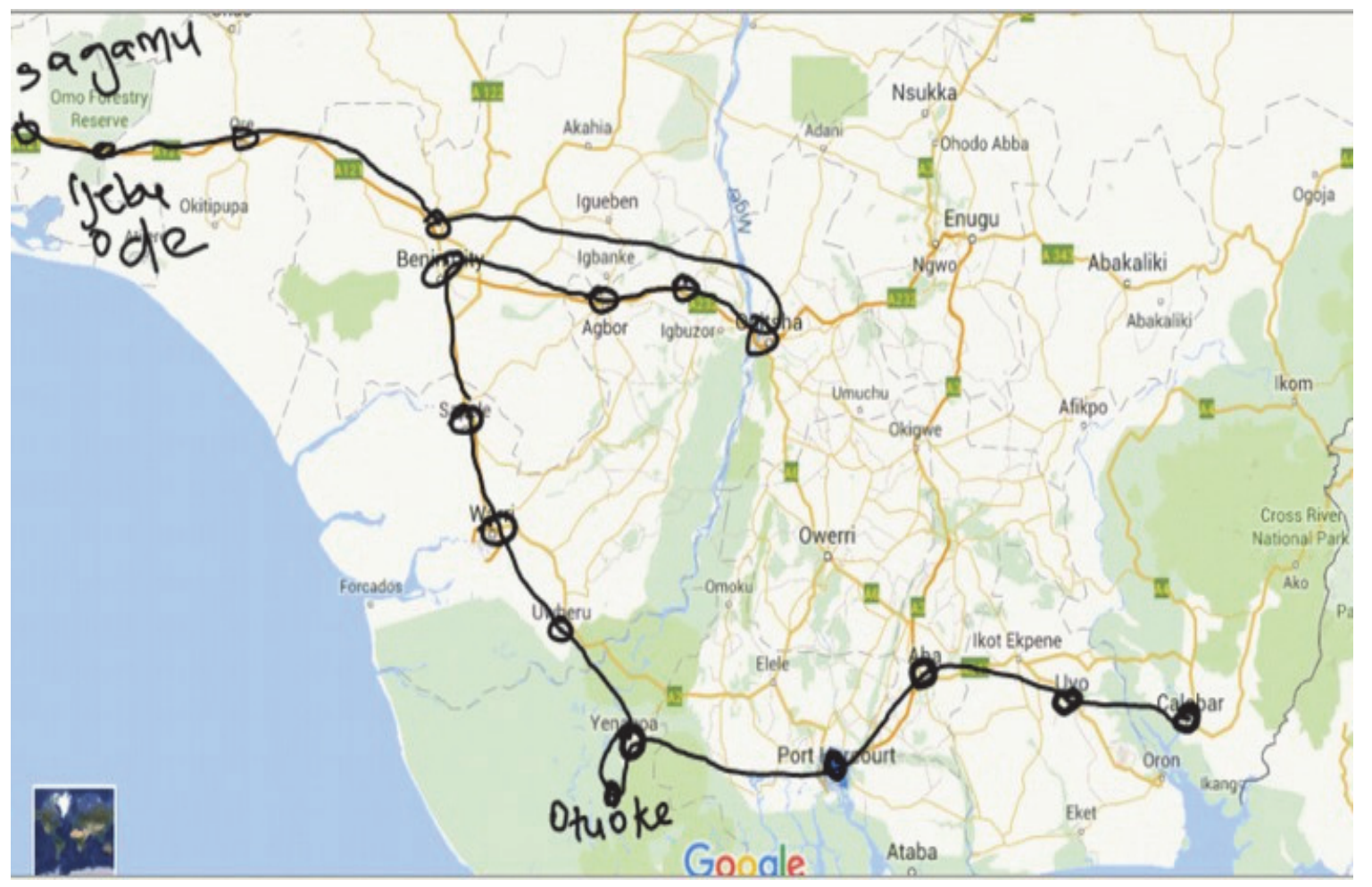

Figure 1. Rail route from Calabar to Lagos

Table 1. Beneficiary states

\begin{tabular}{ccc}
\hline No & State & Population in Millions \\
\hline 1 & Rivers & 5.198 \\
2 & Bayelsa & 1.704 \\
3 & Delta & 4.112 \\
4 & Edo & 3.233 \\
5 & Ondo & 3.460 \\
6 & Ogun & 5.20 \\
7 & Lagos & 23 \\
\hline
\end{tabular}

\subsection{Social - Economic Impact}

Tourism: According to Hasall (1996) in Hoyle and Knowles (1996) Transport forms an integral part of recreational and its an aid to access recreational opportunities, therefore reduction in the relative costs of travel, and in the frictional effects of distance will increase the demand for recreational trips. He however 
submits that those most constrained as a result of poor mobility are women, especially in Sub Saharan Africa who lack access to cars, children and the elderly. Along the rail corridor, several tourist sites are located in each of the state shown in table 1. Part of the problem in accessing these sites is the poor road accessibility and the unsafe nature of Nigerian roads which many have come to fear, due to accidents and the frequent kidnappings. For instance, the rail will give the Osun Oshogbo and Igue festivals a big boost as tourists would be able to travel from Lagos and Enugu airports by train to the nearest stations to the tourist sites. Also, the annual Calabar carnival which is variously tagged Africa's biggest street party will receive a bigger boost as more participants can travel easily to the city. Obudu Cattle ranch and mountain resort that play host to Africa's biggest mountain race would have more spectators as many Nigerians could travel by train to Calabar to attend the events. Also, the marine magnificence of the Qua falls in Akamkpa, Tinapa business resort/ Free trade zone among others will become more prominent on Nigerias tourist map.

Reduction in gridlock: The Lagos Ibadan expressway has become a nightmare to motorists and other travelers. Many people have lost their lives to accidents and the menace of kidnappers and armed robbers. The proposed rail line will remove some of the travelers from the road, especially those coming in from the eastern region, who sometimes spend as much time in gridlock than the total travel time it would have taken to make the journey. Apart from reducing fares, it will be easier to move various goods from the west to the east and will improve the wealth of traders as it will be easier to move their goods through train. Most east bound goods emanate from the Apapa Port Complex, the proposed rail plan as earlier mentioned is designed to have branch lines to every port along the corridor. This will be a big boost to the proposed seaport at Badagry and Epe. An improved transport network irrespective of the mode, reliefs travel burden by providing alternative to the travelers, reduce travel time and on the long run improve productivity. (Kadiyali, (2008)

Improve Safety: Various data sources from show that the Lagos/Ore/Benin/Onitsha road corridor has one of the highest accident records of any highway in Nigeria. This is due to the high density of vehicular traffic, bad roads and reckless driving. The train will provide travelers an alternative, rather than being captive travelers. According to Bun, (2012). Nigeria loses about N80b Naira annually to road traffic accidents. He stated further that, of all persons involved in road traffic accidents in Nigeria, 29.1 per cent suffer disability and 13.5 per cent are unable to return to work.

"The regular occurrence of vehicle accidents, often fatal, on the Lagos-Ibadan expressway calls for urgent national concern, and the intervention of the authorities. Barely two weeks after a most horrendous accident occurred at the Berger section of the LagosIbadan Expressway which claimed about sixty lives with 23 vehicles burnt, there was a similar accident at Ibafo on the same expressway on Sunday, September 5, resulting in the death of six persons, including children, and the loss of 13 vehicles to an inferno, while scores of people sustained injuries". (Nairaland, extracted Jan. 4, 2020)

When the Nigerian Bureau of Statistics (NBS) estimated that no fewer than 2,598 Nigerians died in road accidents between October 2017 and March 2018; a six-month period, many ascribed most of the deaths to accidents that occurred on the LagosIbadan Expressway during the period. (Tomi Falade-Independent. Sat. 4. 2020)

It is gladdening to note however, that the commissioning of the Lagos Ibadan Rail in the first instance and the construction of the East-West Rail, will drastically reduce the traffic on the road and thereby reduce accidents.

Arguably, the reliability and safety on rail systems under normal circumstances is relatively quite higher than other modes because the separation of the operations and overall internal control. Statistics show that the death rate associated with automobile travel is 0.91 per 100 million passenger miles, while that of intercity and commuter rail is 0.06 (Grava, 2003). Road Transport is increasingly becoming unsafe with the spectacular growth of traffic on the roads. Kadyali \& Lal (2013). For example, a palm produce farmer in Aba can put his produce on a railway coach, and the next day he is in a big market in a town like Benin, where he will sell his produce and go back home by the next scheduled train service. No time wasted in needless traffic or at different road blocks. No chance of robbery on the way and the reduced 
cost on freight will put more money in his pocket and that of his family — resulting in more money in the system

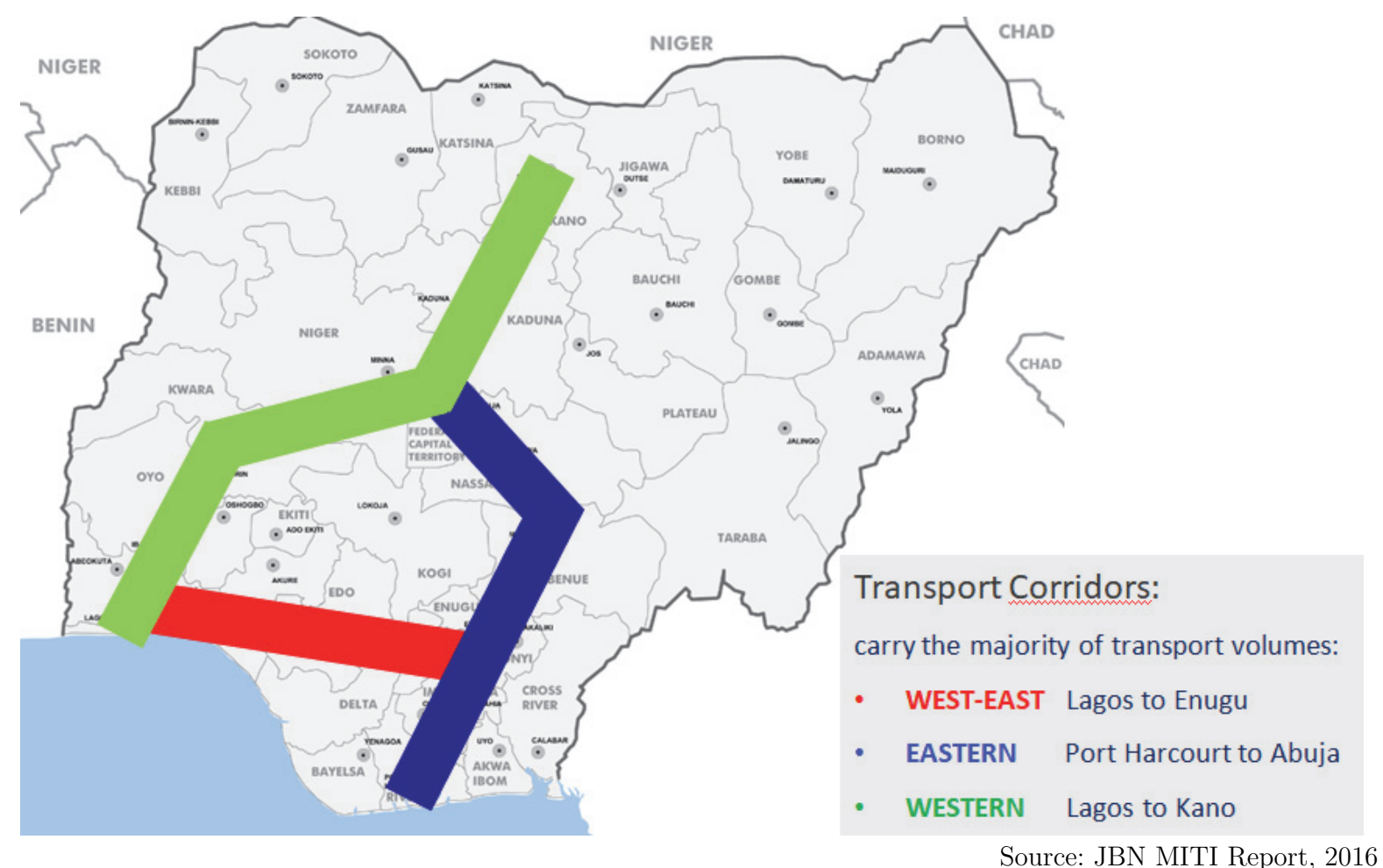

Figure 2. East-west trade connection carries heavier traffic

Reduce unemployment: The operations of the rail will boost employment generation especially along its stations. It will increase taxi operations in those towns that will have more visitors to carry. Rail construction is a labour intensive operation, this means that thousands of people will be employed in the value chain; it provides employment in three categories; one is the pre construction site preparation, two during construction and thirdly during operations. It will help absorb unutilized labour and reduce unemployment. It will enhance job and labor force accessibility, thus, it will result in larger pool of employees available for the job market. Also, the three regions produce a variety of cash crops which are now exported. For instance it will be easy to move timber from the forests of Ogun and Edo state to Lagos for export, the palm oil producers in the east can easily explore wider markets in the west, smoked fish from Bayelsa, Delta and Rivers state could have more utility value when moved safely and cheaply by rail. Yams destined for the Lagos markets that come in from Benue, Taraba, Adamawa and Enugu via Onitsha can be moved faster, safely and cheaply to markets in the west where population demand is getting quite high due to the influence of Lagos

Increase productivity: The ease of doing business depends partly to ability to move easily. Where people are unable to move easily, the likelihood of the numbers business they can engage in daily will reduce. The rail will assist workers and traders to reduce the cost of doing business, boost income and enhance goodwill. The proposed rail service will increase the accessibility of people and businesses to reach jobs, services, goods and activities, productivity also increases

Open new markets: Rail passengers in Nigeria decreased from 14 million in 1980 to less than 1 million in 2005, while rail freight went from 3 million tones to less than 500,000 tones during the same period. (Oviedo etal, 2017). The profit made on goods depends on how far it can penetrate markets. If a good is limited to goods only within its primary threshold of production, the income from the good, will be limited to the purchasing power of the local residents. However, transport provides the means in which goods can penetrate or consumed in distant markets. The proposed east-west rail will open up new markets for local producers. 
Enhance supply chain efficiency: When businesses are clustered, it is easier and quicker for them to reach their suppliers and customers. Easier access to needed supplies and materials and faster delivery time to customers will lead to lower transportation and inventory carrying costs while increasing both productivity and profitability.

Reduce cost of energy: The large volume of motor cars plying the roads consume considerable amount of fuel with its attendant environmental pollution. This is suggesting that we have not yet taken the topic of transport energy sufficiently seriously (Farrington, 1996) In Hoyle and Knowles (1996), he discussed further that the car emerges as the greatest single factor in transport's increasing energy use. Although its consumption is gradually decreasing, it however shows that before the large consideration of electric cars in the UK, it is was responsible for $60 \%$ of all transport energy consumption.

Current Statistics available from the Nigeria national Petroleum Corporation (NNPC) shows that Nigeria consumes 41 million litres/day of fuel and in 2008, transport represented $80 \%$ of consumption of petroleum products. According to data from the International Energy Agency (2014), transport accounts for $45 \%$ of total CO2 emissions in the country. Nigeria is the second producer of carbon dioxide in SubSaharan Africa (Oviedo etal, 2017), this is because most movement are land based. The introduction of the East-West rail to the carriage capacity of the country will reduce these externalities. For instance, various evaluations had shown that moving freight by rail is 4 times more fuel efficient than moving freight on the highway. According to Grava (2003), once trains are in motion, it takes very little power to maintain forward progress. Which means that, in terms of energy consumption per passenger, heavy rail is the most preferred as long as the cars are reasonably occupied. It will therefore be far cheaper for business men and women to move their freights by rail. The east-west rail line will provide this opportunity to reduce cost of doing business and reduce greenhouse effect.

\section{Conclusion}

The proposed East-West rail Line when completed would serve as a turn-key project that will improve the economic prosperity of the two regions. It will give place and time utility to goods; it will improve individual, corporate and regional productivity. Others include the reduction in accidents; expand existing markets carbon prints, and insecurity. It will also improve life styles, regional integration and reduce the cost of doing business. Above all, it will expand the passenger carriage capacity for passengers and goods and reduce avoidable accidents and the carbon footprint along the corridor.

\section{References}

1. Asian Development Bank Staff Working Paper. 2010. Sustainable Transport Initiative Operational Plan. Asian Development Bank.2010 Philippines

2. Boarnet, M. 1996. The Direct and Indirect Economic Effects of Transportation Infrastructure. Working paper 1996. Institute of Transportation Studies, University of California

3. Bun, K. 2012. Nairaland, extracted Jan. 4, 2020

4. Eze, B. 2012. Road Traffic Accidents in Nigeria: A Public Health Problem. Afrimedic Journal 36 Volume 3, No. 2, July -December, 2012. P35

5. Farrington, J. 1996. in Hoyle and Knowles.1996. Transport, Environment and Energy. Modern Transport Geography. John Wiley \& Sons Ltd, UK. 1996

6. Grava. 2003. Urban transportation Systems p652-653. Macgraw-Hill 2003

7. Hanson, S \& Giuliano. 2004. The Geography of Urban Transportation. (3 ${ }^{\text {rd }}$ Edition). Guilford Press. New York

8. Hoel, L, Garber, N.L, and Sadek A.W. 2008. Transportation Infrastructure Engineering: a multimodal Integration. Nelson, Canada

9. Hoyle and Knowles. 1996. Modern Transport Geography John Wiley \& Sons; 2 edition (January 7, 1999)

10. Modern Transport Geography Julius Berger Nigeria Plc. 2016. Master Plan for Integrated Transport Infrastructure (MITI)

11. Kadyali, L.R \& Lal, N.B. 2013. Principles and Practices of Highway Engineering. Khana Publishers Delhi-6

12. Kadiyali L.R (2008). Traffic Engineering and Transport Planning. Khanna Publishers 2-B Nath Market, Nai Sarak, Delhi-110006. 
13. Master Plan for Integrated Transport Infrastructure (MITI) Report. 2002. Federal Ministry of Transport, Abuja, Nigeria

14. Nigeria Transport Survey (NTS Volume 2 main Report, 2006). Federal Ministry of Transport, Abuja, Nigeria

15. Nigeria National Petroleum Corporation (NNPC) 2019. Annual Statistics.

16. Oviedo, D, Julio D, Hickman R and Asenime, C. 2017. Transport and Mobilities: Meeting the Needs of Vulnerable Population in Developing Cities.

17. Oyesiku, K. 2010. New Cities in Urban and Regional Planning. Longman, Lagos P1 